\title{
Recent Phylogeographic Studies Revealed Distinct lineages In Penaeid Shrimps
}

\author{
Mahbub Alam MM ${ }^{1}{ }^{2 *}$, Snæbjörn Pálsson ${ }^{1}$ \\ ${ }^{1}$ Department of Life and Environmental Sciences, University of Iceland, 101 Reykjavik, Iceland \\ ${ }^{2}$ Sylhet Agricultural University, Bangladesh
}

Submission: February 10, 2018; Published: June 14, 2018

Corresponding author: Mahbub Alam MM, Faculty of Fisheries, Sylhet Agricultural University, 3100 Sylhet, Bangladesh, Email: mma3@hi.is

\begin{abstract}
Phylogeographic studies of Penaeid shrimps have revealed genetic divergence among populations between known biogeographic barriers in the western Indian Ocean, between the Bay of Bengal and the south-eastern Africa, and across the Sunda-Shelf and the Isthmus of Kra. The phylogeographic lineages identified should be considered as evolutionary significant units (ESUs) or conservation units and should be considered in the management of the Penaeids, both in aquaculture and fisheries in order to maintain the large diversity within the species in the Indo-Pacific region.
\end{abstract}

\section{Introduction}

The penaeid shrimps represent about 30 species [1], including some of the most commercially important for both aquaculture and capture fisheries. They belong to the genus Penaeus sensu lato [2], which is a giant group of marine shrimps or prawns [3,4] with six subgenera [5-7]. Pérez Farfante and Kensley (1997) ranked the six subgenera as genuses (i.e. Fenneropenaeus, Penaeus, Farfantepenaeus, Litopenaeus, Melicertus, Marsupenaeus). However, several studies, based on variation in mitochondrial and nuclear genes, refuted the recent taxonomic revision of Penaeus s.l. proposed by Pérez Farfante and Kensley (1997) and even the formation of previous six subgenera [1,3,4]. The taxonomic revision of Penaeus s.l. was considered to be controversial as its monophyly was supported [1,4]. Thus, phylogenetics of penaeid shrimps has been a debated issue and several species are known for a large molecular variation.

Phylogeography is an important tool to study the historical processes associated with geographical distributions of individuals $[8,9]$. It can play an important role in defining evolutionary significant units (ESUs) or conservation units characterized by reciprocally monophyletic mitochondrial DNA lineages [10] and in understanding how the range of species changed due to historical biogeographical processes [9] e.g. after the last glacial period of Ice Age. It can provide a valuable platform for studying selection and adaptation of organisms which is enriched by an understanding of the biology and ecology of the studied organisms [11]. A number of studies have applied at different depth, using mitochondrial DNA and nuclear markers to infer genetic patterns in prawns and shrimps and have revealed distinct lineages associated with known biogeographic barriers i.e. the Sunda-Shelf [12-22] and the Isthmus of Kra [23,24,]. The phylogeographic patterns in the Indo-West Pacific region can be explained largely by historical sea-level fluctuations associated with the known biogeographic barriers: the Sunda-shelf and the Isthmus of Kra, which connected the Malay Peninsula, Sumatra, Java and Borneo with extensive land bridges at $50 \mathrm{~m}$ depth contour below present level around $11 \mathrm{kyrs}$ ago [25]. The main aim of the review is to unveil the recent phylogeographic patterns of the major Penaeid prawn and shrimp species.

\section{Phylogeography of Penaeid Shrimps}

The genus Penaeus is considered to have originated in the center of the Indo-West Pacific region and dispersed eastward and westward forming two groups (i.e. western Pacific and Indian Oceans), which spread during the Tertiary and Pleistocene periods $[12,18]$. Such diversification has also been observed within Penaeus monodon [2] where populations east and west of the Sunda-Shelf are characterized by distinct mtDNA lineages [14]. Based on mtDNA, P. monodon populations in the Indo-Pacific region are broadly structured as three groups, i.e. in South-East Africa, South and South-East Asia and the Pacific $[14,15,18]$. The South and South-East Asia populations are further divided into two groups, west and east of the Sunda-shelf $[2,14,15,26]$. The populations in the South-East Africa group are unique and genetically differentiated from the other main groups, which are 
partially admixed $[2,15,26]$. Due to the large divergence between South-East Asia and South-East Africa haplotypes, the South-East Asia populations are considered to have migrated towards the Indo-West Pacific region [14]. Studies based on the mitochondrial control region (CR), group the haplotypes into three monophyletic lineages (A, B and C) $[16,17]$. The most recent common ancestor of the three monophyletic CR lineages (A, B and C) dated back to 13.2 (CI: 9.6 - 17.4) Mya, and 8.2 (CI: 5.6 - 10.8) Mya for lineages A and $B$ [21]. Individuals in lineage $C$ were found in all specimens in west of the Sunda-Shelf from Madagascar to Bangladesh, except for two specimens from Sri Lanka [21]. Lineages A and B were solely found in populations from the south-east Asia and the Pacific Ocean regions. The distances between populations based on the 16S rRNA gene provide further support for the split based on CR. The large divergence in the $\mathrm{CR}$ region between these three groups suggest they may even be different cryptic species [21].

Analyses of phylogeographic patterns in Fenneropenaeus indicus (H. Milne-Edwards 1837) have similarly reavealed distinctive groups, confining two main phylogeographic lineages or even cryptic species. One group is found in the eastern (includes Bangladesh, Sri Lanka, India and West Australia) and the second in the western Indian Ocean regions (includes South-Eastern Africa, Oman and Iran, and a single individual from Thailand), which diverged well before the onset of Ice age 5.4Myr ago [22]. A further split is observed within the eastern group which has occurred during the Ice Age [22].

Phylogeographic analysis of Penaeus semisulcatus De Haan 1844 showed clear patterns in the Indo-West Pacific region with a split across the Sunda-Shelf. The Indian Ocean samples (Bangladesh, Sri Lanka, India, Malaysia and Iran) clustered together in a West Sunda-Shelf group but the samples from China and Philippines clustered in an East Sunda-Shelf group [20]. Individuals from Iran showed admixture of two lineages and high nucleotide diversity, one shared with Bay of Bengal and possibly western Indian Ocean populations and one distinct [20]. Two main lineages were observed in Metapenaeus monoceros (Fabricius 1798): one in the eastern Indian Ocean, including individuals from Bangladesh, and the second in the western Indian Ocean, including individuals from Kenya and Tanzania [19].

\section{Discussion}

The phylogeography and the diversity of the penaeid prawn and shrimps show different mtDNA lineages or evolutionary significant units (ESUs) in different regions of the Indo-Pacific Oceans which can be linked to the east and west biogeographic zones of the Sunda-Shelf and the western Indian Ocean Province [19-22]. The evidence for these phylogeographic splits varies somewhat among the species. The overall phylogeographic patterns in the studied prawn and shrimps, based on mitochondrial DNA markers, closely follows the geographic structure in the West Indo- Pacific region, where neighbouring populations are generally more similar to each other than those sampled from further away
[19-22]. In general, two to four phygeographic lineages or ESUs, associated with different known biogeographic barriers, were observed for the studied species:

I. The western Pacific Ocean, west of the Sunda-Shelf (includes P. monodon, P. semisulcatus, M. rosenbergii),

II. The South-East Asia, aroud the Sunda-Shelf but south-east of the Isthmus of Kra (includes P. monodon, M. rosenbergii),

III. The Bay of Bengal region, west of the Sunda-Shelf and the Isthmus of Kra (includes F. indicus, P. monodon, P. semisulcatus, M. monoceros, M. rosenbergii) and

IV. The south-eastern Africa (includes F. indicus, P. monodon, M. monoceros, possible P. semisulcatus), coming from a different biogeographical province, the Western Indian Province [11,1922].

An additional lineage of $F$. indicus was observed between the Bay of Bengal and the western Indian Ocean, in India and Sri Lanka [20].

Biogeographic events related to the Sunda-Shelf are known to have affected diversification of marine organisms in the IndoWest Pacific region $[27,28]$, and have been proposed to explain the splits (among South Pacific, eastern Australia and south-east Asia) and a split (between eastern Indian Ocean and western Pacific) within P. monodon as the two oceans were completely separated at certain times during the Tertiary and Pleistocene periods [18]. The oldest divergence within $P$. monodon (estimated as the most recent common ancestor for all lineages), based on the mutation rate for the $\mathrm{CR}$, predates the main temperature fluctuations and sea level changes, which started around 5.6 Mya or at the onset of the Pleistocene, when the Indian and Pacific Oceans were completely separated with extensive land bridges [14,25]. An admixture of all lineages may have occurred around the Sunda-Shelf in Indonesia, Thailand, Vietnam and China, when the Indian and Pacific Oceans connected through the Sunda-Shelf or even after the last glacial period [29]. The admixture appears to have been directional, as lineage $\mathrm{C}$ of $P$. monodon from the Bay of Bengal area, rather than from the distinct African populations as proposed by Benzie et al. [14], may have migrated eastwards through the region, but only a small number of lineage A individuals have been found west of the region, in western Thailand and Sri Lanka. Baldwin et al. [12] concluded that the Penaeus genus originated in the center of the Indo-West Pacific region and migrated eastwards and westwards forming two groups, in the eastern Pacific and the Indian Ocean. Such divergence has been reported for other Indo-West Pacific species, e.g. in mud crab (Scylla serrata; Forskal 1775) [27], kuruma shrimp (Penaeus japonicus; Bates 1888) [28]. The SundaShelf may not be the only geographic barrier in the Indian Ocean [22]. The large split between the African samples and the samples from India, Sri Lanka and Bangladesh might have occurred due to large geographical distances [22], and due to different surface and subsurface equatorial ocean currents in western Indian Ocean 
[30]. A strong concordance between intrspecific and biogeographic boundaries have also been reported for several other marine species [31-37].

\section{Conclusion}

To conclude, this review provides an increased knowledge on the phylogeography of penaeid shrimps where distinct lineages should be considered as evolutionary significant units (ESUs) or conservation units, which need regional cooperation for conservation and management. The large diversification observed in the mtDNA have revealed hidden diversity or even cryptic species which warrants further evaluation of the morphological and genomic divergence of these species.

\section{References}

1. Ma KY, Chan T-Y, Chu KH (2011) Refuting the six-genus classification of Penaeus s.l. (Dendrobranchiata, Penaeidae): a combined analysis of mitochondrial and nuclear genes. Zoologica Scripta 40(5): 498-508.

2. Kumar N, Lakra WS, Majumdar KC, Goswami M, Ravinder K (2007) Genetic diversity in the Indian population of Penaeus monodon (Fabricius, 1798) as revealed by mtDNA sequence analysis. Aquatic Resources 38(8): 862-869.

3. Lavery S, Chan TY, Tam YK, Chuc KH (2004) Phylogenetic relationships and evolutionary history of the shrimp genus Penaeus s.l. derived from mitochondrial DNA. Mol Phylogenet Evol 31(1): 39-49.

4. Flegel TW (2007) The right to refuse revision in the genus Penaeus. Aquaculture 264(1-4): 2-8.

5. Pérez Farfante I, Kensley B (1997) Penaeoid and Sergestoid Shrimps and Prawns of the World (Keys and Diagnoses for the Families and Genera). Muséum National d'Histoire Naturelle, Paris, France.

6. Tirmizi NW (1971) Marsupenaeus, a new subgenus of Penaeus Fabricius, 1798 (Decapoda, Natantia). Pakistan Journal of Zoology 3 : 193-194.

7. Burukovsky RN (1972) Nekotorye voprosy sistematiki i rasprostraneniya krevetok roda Penaeus. Rybokhozyaistvennye issledovaniya v Altanticheskom okeane, Trudy AltantNIRO, Kaliningrad 2: 3-21.

8. Lowe A, Harris S, Ashton P (2006) Ecological genetics: design, analysis, and application. Blackwell Publishing Ltd, USA.

9. Paule L, Krajmerova D, Romsakova I, Schlosserova D (2012) Conservation genetics: New tool for wildlife management and nature conservation. In: Proceedings of International Symposiam on HuntingModern aspects of sustainable management of game population, Zemun-Belgrade, Serbia, 22-24 June 2012.

10. Moritz C (1994) Defining 'Evolutionarily Significant Units' for conservation. Trends Ecol Evol 9(10): 373-375.

11. Bowen BW, Shanker K, Yasuda N, Malay MCD, von der Heyden S, et al. (2014) Phylogeography unplugged: comparative surveys in the genomic era. Bulletin of Marine Science 90(1): 13-46.

12. Baldwin JD, Bass AL, Bowen BW, Clark WH (1998) Molecular phylogeny and biogeography of the marine shrimp Penaeus. Mol Phylogenet Evol 10(3): 399-407.

13. Duda JTF, Palumbi SR (1999) Population structure of the black tiger prawn, Penaeus monodon, among western Indian Ocean and western Pacific populations. Marine Biology (1999) 134: 705-710.

14. Benzie JAH, Ballment E, Forbes AT, Demetriades NT, Sugama K, et al. (2002) Mitochondrial DNA variation in Indo-Pacific populations of the giant tiger prawn, Penaeus monodon. Mol Ecol 11(12): 2553-2569.
15. You EM, Chiu TS, Liu KF, Tassanakajon A, Klinbunga S, et al. (2008) Microsatellite and mitochondrial haplotype diversity reveals population differentiation in the tiger shrimp (Penaeus monodon) in the Indo-Pacific region. Anim Genet 39(3): 267-277.

16. Zhou FL, Jiang SG, Jiang YJ, Huang JH, Ma ZM (2009) Population genetic structure of the tiger prawn (Penaeus monodon) in the coastal waters of South China, based on mitochondrial DNA control region sequences. Applied Ichthyology 25(4): 411-416.

17. Walther E, Schöfl G, Mrotzek G, Haryanti, Sugama K, et al. (2011) Paralogous mitochondrial control region in the giant tiger shrimp, Penaeus monodon (F.) affects population genetics inference: A cautionary tale. Mol Phylogenet Evol 58(2): 404-408.

18. Waqairatu SS, Dierens L, Cowley JA, Dixon TJ, Johnson KN, et al. (2012) Genetic analysis of Black Tiger shrimp (Penaeus monodon) across its natural distribution range reveals more recent colonization of Fiji and other South Pacific islands. Ecol Evol 2(8): 2057-2071.

19. Alam MMM (2016) Origin and population structure of major prawn and shrimp species in Bangladesh, PhD dissertation, Faculty of Life and Environmental Sciences, University of Iceland, Iceland, pp. 162.

20. Alam MMM, de Croos MDST, Pálsson S (2016a) Mitochondrial DNA variation reveals distinct lineages in Penaeus semisulcatus (Decapoda, Penaeidae) from the Indo-West Pacific Ocean. Marine Ecology 38(2): e12406.

21. Alam MMM, Westfall KM, Pálsson S (2016b) Mitogenomic variation of Bangladesh Penaeus monodon (Decapoda, Penaeidae) and reassessment of its phylogeography in the Indo-West Pacific region. Hydrobiologia 763(1): 249-265.

22. Alam MMM, Westfall KM, Pálsson S (2015) Mitochondrial DNA variation reveals cryptic species in Fenneropenaeus indicus. Bulletin of Marine Science 91(1): 15-31.

23. Hurwood DA, Dammannagoda S, Krosch MN, Jung H, Salin KR, et al. (2014) Impacts of climatic factors on evolution of molecular diversity and the natural distribution of wild stocks of the giant freshwater prawn (Macrobrachium rosenbergii). Freshwater Science 33(1): $217-$ 231.

24. De Bruyn M, Nugroho E, Hossain MM, Wilson JC, Mather PB (2005) Phylogeographic evidence for the existence of an ancient biogeographic barrier: the Isthmus of Kra Seaway. Heredity (Edinb) 94(3): 370-378.

25. Voris HK (2000) Maps of Pleistocene sea levels in South Asia: shorelines, river systems and time durations. Journal of Biogeography 27(5): 1153-1167.

26. Mandal A, Rao D, Karuppaiah D, Gopalakrishnan A, Pozhoth J, et al (2012) Population genetic structure of Penaeus monodon, in relation to monsoon current patterns in Southwest, East and Andaman coastal waters of India. Gene 491(2): 149-157.

27. Gopurenko D, Hughes JM, Keenan CP (1999) Mitochondrial DNA evidence for rapid colonisation of the Indo-West Pacific by the mudcrab Scylla serrata. Marine Biology 134(2): 227-233.

28. Tsoi KH, Chan TY, Chu KH (2007) Molecular population structure of the kuruma shrimp Penaeus japonicus species complex in western Pacific. Marine Biology 150(6): 1345-1364.

29. Bird MI, Taylor D, Hunt C (2005) Palaeoenvironments of insular Southeast Asia during the Last Glacial Period: a savanna corridor in Sundaland? Quaternary Science Reviews 24(20-21): 2228-2242.

30. Pidwirny M (2006) Surface and Subsurface Ocean Currents: Ocean Current Map. Fundamentals of Physical Geography, $\left(2^{\text {nd }} e d n\right)$.

31. Ewers-Saucedo C, Pringle JM, Sepúlveda HH, Navarrete JBS, Wares JP (2016) The oceanic concordance of phylogeography and biogeography: A case study in Notochthamalus. Ecol Evol 6(13): 4403-4420. 
32. Altman S, Robinson JD, Pringle JM, Byers JE, Wares JP (2013) Edges and overlaps in Northwest Atlantic phylogeography. Diversity 5(2): 263-275.

33. Dawson MN (2001) Phylogeography in coastal marine animals: a solution from California? Journal of Biogeography 28(6): 723-736.

34. Wares JP (2002) Community genetics in the Northwestern Atlantic intertidal. Mol Ecol 11(7): 1131-1144.

35. Pelc RA, Warner RR, Gaines SD (2009) Geographical patterns of genetic structure in marine species with contrasting life histories. Journal of Biogeography 36(10): 1881-1890.
36. Haye PA, Segovia NI, Munoz-Herrera NC, Galvez FE, Martinez A, et al. (2014) Phylogeographic structure in benthic marine invertebrates of the southeast Pacific coast of Chile with differing dispersal potential. PLos One 9(2): e88613.

37. Pérez Farfante I (1969) Western Atlantic shrimps of the genus Penaeus. Fisheries Bulletin (USA) 67: 461-591.

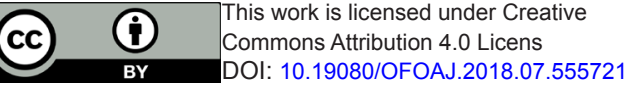

Your next submission with Juniper Publishers will reach you the below assets

- Quality Editorial service

- Swift Peer Review

- Reprints availability

- E-prints Service

- Manuscript Podcast for convenient understanding

- Global attainment for your research

- Manuscript accessibility in different formats

( Pdf, E-pub, Full Text, Audio)

- Unceasing customer service

Track the below URL for one-step submission https://juniperpublishers.com/online-submission.php 